\title{
Effects of irrigation water salinity on soil salt content distribution, soil physical properties and water use efficiency of maize for seed production in arid Northwest China
}

\author{
Chengfu Yuan ${ }^{1,2}$, Shaoyuan Feng ${ }^{1,3^{*}}$, Juan Wang ${ }^{1}$, Zailin Huo ${ }^{3}$, Quanyi $\mathrm{Ji}^{1}$ \\ (1. College of Hydraulic, Energy and Power Engineering, Yangzhou University, Yangzhou 225009, Jiangsu, China; \\ 2. Department of Hydraulic Engineering, Jiangxi Water Resources Institute, Nanchang 330013, China; \\ 3. Centre for Agricultural Water Research in China, China Agricultural University, Beijing 100083, China)
}

\begin{abstract}
In order to explore the use of groundwater resources, field experiments were conducted for three consecutive years during 2012-2014 in the Shiyang River basin of Northwest China. Irrigation was conducted using four different water salinity levels that were arranged in a split plot design. These four water salinity levels were s0, s3, s6 and s9 (0.71, 3, 6 and $9 \mathrm{~g} / \mathrm{L}$, respectively). The soil salt content, soil bulk density, soil porosity, saturated hydraulic conductivity, plant height, leaf area index and yield of maize for seed production were measured for studying the effects of saline water irrigation on soil salt content distribution, soil physical properties and water use efficiency. It was observed that higher salinity level of irrigation water and long duration of saline water irrigation resulted in more salt accumulation. Compared to initial values, the soil salt accumulation in 0-100 cm soil layer after three years of experiments for s0, s3, s6 and s9 was $0.189 \mathrm{mg} / \mathrm{cm}^{3}, 0.654 \mathrm{mg} / \mathrm{cm}^{3}$, $0.717 \mathrm{mg} / \mathrm{cm}^{3}$ and $1.135 \mathrm{mg} / \mathrm{cm}^{3}$, respectively. Both greater salt levels in the irrigation water and frequent saline water irrigation led to greater soil bulk density, but poorer soil porosity and less saturated hydraulic conductivity. The saturated hydraulic conductivity decreased with increase in soil bulk density, but increased with improvement in soil porosity. It was noted that the maize height, leaf area index and maize yield gradually decreased with increase in water salinity. The maize yield decreased over $25 \%$ and the water use efficiency also gradually declined when irrigated with water containing $6 \mathrm{~g} / \mathrm{L}$ and $9 \mathrm{~g} / \mathrm{L}$ salinity levels. However, maize yield following saline water irrigation with $3 \mathrm{~g} / \mathrm{L}$ decreased less than $20 \%$ and the decline in water use efficiency was not significant during the three-year experiment period. The results demonstrate that irrigation with saline water at the level of $6 \mathrm{~g} / \mathrm{L}$ and $9 \mathrm{~g} / \mathrm{L}$ in the study area is not suitable, while saline water irrigation with 3 $\mathrm{g} / \mathrm{L}$ would be acceptable for a short duration together with salt leaching through spring irrigation before sowing.

Keywords: saline water irrigation, soil salt content distribution, soil physical properties, maize for seed production, water use efficiency

DOI: $10.25165 / j . i j a b e .20181103 .3146$
\end{abstract}

Citation: Yuan C F, Feng S Y, Wang J, Huo Z L, Ji Q Y. Effects of irrigation water salinity on soil salt content distribution, soil physical properties and water use efficiency of maize for seed production in arid Northwest China. Int J Agric \& Biol Eng, 2018; 11(3): 137-145.

\section{Introduction}

Due to arid climate and little rainfall, the Shiyang River basin is a typical interior river basin that faces water shortage and environmental deterioration in arid Northwest China ${ }^{[1]}$. The total amount of water supply in the Shiyang River basin is 2.877 billion $\mathrm{m}^{3}$, of which 2.485 billion $\mathrm{m}^{3}$ is used for agriculture, which accounts for $86.4 \%$ of the total water supply ${ }^{[2]}$. Agricultural irrigation is the major consumer of available water resources in any arid region. For the arid Northwest China facing shortage of surface water resources, groundwater is also an important water source for social

Received date: 2016-12-22 Accepted date: 2018-03-16

Biographies: Chengfu Yuan, $\mathrm{PhD}$ candidate, Lecturer, research interests: agricultural soil and water environment and water-saving irrigation, Email: cfyuan1989@163.com; Juan Wang: Lecturer, research interests: soil and water conservation, Email: blesswangj@hotmail.com; Zailin Huo, Professor, research interests: water resource and environment and water-saving irrigation, Email: huozl@cau.edu.cn; Quanyi Ji, Master, research interests: water-saving irrigation, Email: jqy19891031@163.com.

*Corresponding author: Shaoyuan Feng, Professor, research interests: water resource and environment and water-saving irrigation. College of Hydraulic, Energy and Power Engineering, Yangzhou University, Yangzhou 225009, Jiangsu, China. Tel: +86-514-87969205, Email: syfeng@yzu.edu.cn. and economic development, maintaining the ecological environment and agricultural irrigation. Due to excessive exploitation of local water resources, the groundwater salinity tend to increase with every passing year ${ }^{[3]}$. In order to make up for shortage of fresh water resources and ensure steady development of agricultural production in arid district, saline water irrigation has been widely used in agricultural production. Dozens of countries around the world (e.g., the U.S.A., Israel, Syria, Japan, Italy and Australia) have used salt water for irrigation and have gradually developed relatively mature technological systems. The traditional surface irrigation method was used in the southwest of USA with the irrigation water salinity of $2.5-4.89 \mathrm{~g} / \mathrm{L}$. The practice showed that the cotton yields were similar or higher than the production with traditional fresh water irrigation method ${ }^{[4]}$. In west Australia, salt water with salinity over $3.5 \mathrm{~g} / \mathrm{L}$ was successfully used on a short-term basis to irrigate apple trees and grapes $^{[5]}$. Similarly, in Israel underground brackish or salt water with a salinity of 1.2-5.6 g/L was widely used as the major source of agricultural irrigation for farm irrigation, spray irrigation and drip irrigation ${ }^{[6]}$. Most studies on saline water irrigation have focussed on its influence on soil water-salt movement, physical and chemical properties of the soil, and on crop growth. Many researchers have also studied salt accumulation in the soil during 
saline water irrigation ${ }^{[7-10]}$. Results show that large irrigation quota will cause the salt in the irrigation water to be concentrated deep inside the soil, while a small irrigation quota may lead to salt accumulation in the root region of the soil. Tedeshi et al. ${ }^{[11]}$ used the SWAP model to simulate the water and salt distribution in the soil under saline water irrigation with varying salinity. The study indicated that the accumulated salt content in the soil increases linearly after years of saline water irrigation. The influence of saline water irrigation on physical properties of soil mainly reflects towards the influence of salinity and ion content in the irrigation water on soil permeability ${ }^{[12,13]}$. Increased salinity of irrigation water causes decreased expansion effect of the clay and increased flocculation. With increase in effective porosity of soil, both hydraulic conductivity and soil permeability increased ${ }^{[14]}$. Feigen et al. studied the influence of saline water irrigation on exchangeable sodium and conductivity of the soil. They reported that increase in sodium ion resulted in soil particle contraction, colloid particle separation and swelling, and decreased soil porosity ${ }^{[15]}$. Zartman et al. ${ }^{[16]}$ investigated the variation of physical and chemical properties of sandy and calcareous soil under saline water irrigation. They reported that four years of irrigation led to dramatic increase in conductivity, soluble sodium, calcium, magnesium, and sodium adsorption ratio of the soil solution. The results also implied an evident decrease in hydraulic conductivity of the soil, but soil bulk density and moisture characteristic curve did not change considerably. Variations of the physical and hydraulic properties of the soil will inevitably cause variations of salt and water movement in the soil.

Maize is one of the most important crops in the world and is sensitive to salt content ${ }^{[17-19]}$. Katerji et al. ${ }^{[20]}$ showed that saline water irrigation increased salt stress and hence resulted in reduced leaf water potential, photosynthetic rate, transpiration rate, stomatal conductance and the yield of the maize. Kang et al. ${ }^{[21]}$ demonstrated that an increase in salinity of irrigation water by $1 \mathrm{dS} / \mathrm{m}$ led to a decrease in plant height, fresh weight and dry weight by $2 \%$ and a decrease in maize yield by about $0.4 \%-3.3 \%$. The maize for seed production is one of the main economic crops and the planting area of maize is rapidly increasing in arid Northwest China. With consideration of different soil texture, soil physical and chemical properties, climate conditions, planting types and structure in different regions, we studied the effects of saline water irrigation on soil salt content distribution, soil physical properties and water use efficiency of maize for seed production in arid Northwest China. The study also has an important theoretical significance for saline water irrigation theory to guide agricultural production practice. The objectives of this study were to investigate: (1) the soil salt content distribution and accumulation after different water salinity treatments; (2) the effects of saline water irrigation on soil physical properties (i.e. soil bulk density, soil porosity and saturated hydraulic conductivity); (3) the effects of saline water irrigation on maize for seed production growth parameters (i.e. plant height and leaf area index), yield and water use efficiency.

\section{Materials and methods}

\subsection{General description of the study area}

Field experiments on maize for seed production with saline water irrigation were conducted from April 2012 to October 2014 at the Shiyang River station of China Agriculture University $\left(102^{\circ} 52^{\prime} \mathrm{E}, 37^{\circ} 52^{\prime} \mathrm{N}\right)$. The station is located in Gansu Province of Northwest China. The area is characterized as a typical arid climate zone with an altitude of $1581 \mathrm{~m}$. The average annual rainfall and potential evaporation of the area is $164.4 \mathrm{~mm}$ and $2000 \mathrm{~mm}$ respectively, groundwater depth in the experimental area is about $40 \mathrm{~mm}$. The experiments were conducted with non-weighing lysimeter containing twelve test pits with area of 6.66 square meter $(3.33 \mathrm{~m} \times 2 \mathrm{~m})$ having a depth of 3 meter (Figures 1 and 2). Two test pits were separated by cement concrete and the bottom is a cement floor. The average bulk density of soil in the test pit was $1.48 \mathrm{~g} / \mathrm{cm}^{3}$, field capacity and saturated water content (volumetric water content) were $0.30 \mathrm{~cm}^{3} / \mathrm{cm}^{3}$ and $0.37 \mathrm{~cm}^{3} / \mathrm{cm}^{3}$ respectively. The physical and chemical properties of the soil before experiment are presented in Table 1.

Table 1 Basic physical and chemical properties of soil

\begin{tabular}{cccccc}
$\begin{array}{c}\text { Soil } \\
\text { depth/cm }\end{array}$ & Sand/\% & Silt $/ \%$ & Clay/\% & $\begin{array}{c}\text { Organic } \\
\text { matter } / \mathrm{g} \cdot \mathrm{kg}^{-1}\end{array}$ & Soil textural \\
\hline $0-20$ & 59.79 & 28.22 & 11.99 & 11.76 & Sandy loam \\
$>20-40$ & 53.03 & 31.89 & 15.08 & 7.12 & Sandy loam \\
$>40-100$ & 48.69 & 36.13 & 15.19 & 5.48 & Clay loam \\
\hline
\end{tabular}

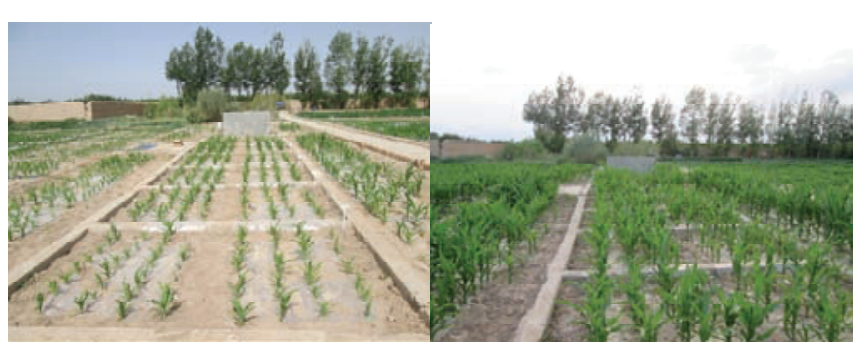

Figure 1 Non-weighing lysimeter

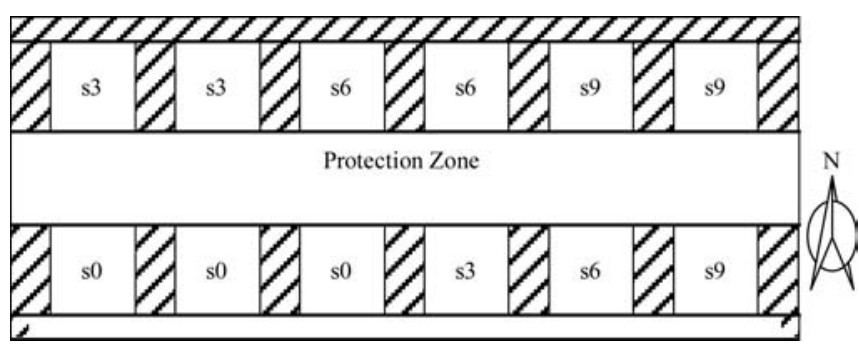

Figure 2 Schematic diagram of non-weighing lysimeter

\subsection{Experimental design}

Irrigation was performed with $0.71 \mathrm{~g} / \mathrm{L} \mathrm{(s0),} 3 \mathrm{~g} / \mathrm{L} \mathrm{(s3),} 6 \mathrm{~g} / \mathrm{L}$ (s6) and $9 \mathrm{~g} / \mathrm{L}$ (s9) level of water salinity. It represented groundwater salinity of the upstream, midstream and downstream of Shiyang River and Minqin Lake area. There were four treatments with three replicates and twelve test pits were laid out by split plot arrangement.

The irrigation water requirement for maize for seed production during each growth stage was decided by the reference crop water requirements and $K_{c}$.

$$
E T_{c}=K_{c} E T_{0}
$$

The $E T_{0}$ was calculated by Penman-Menteith method that recommended by $\mathrm{FAO}$, the $K_{c}$ of maize for each specific growth stage was referred to former study results ${ }^{[22]}$. The total crop water requirements of maize was $555 \mathrm{~mm}$ calculated by Equation (1). According to the local experience, the maize was irrigated 5 times at different growth stage, while the total irrigation quota was the total water amount during the whole growth period. The irrigation schedule was decided as Table 2. The sowing, irrigation and harvest times are shown in Table 3. Spring irrigation was performed once at the volume of about $150 \mathrm{~mm}$, half a month before sowing every year for the purpose of salt leaching and soil water conservation. 
Table 2 Scheme of irrigation under different treatments

\begin{tabular}{|c|c|c|c|c|c|c|c|}
\hline \multirow{2}{*}{ Treatment } & \multirow{2}{*}{$\begin{array}{l}\text { Salt concentration of } \\
\text { irrigation water/g } \cdot \mathrm{L}^{-1}\end{array}$} & \multicolumn{5}{|c|}{ Irrigation quota/mm } & \multirow{2}{*}{$\begin{array}{l}\text { Total irrigation } \\
\text { quota/mm }\end{array}$} \\
\hline & & Jointing stage & Booting stage & Tasseling stage & Filling stage & Maturity stage & \\
\hline s0 & 0.71 & 120 & 120 & 105 & 105 & 105 & 555 \\
\hline s3 & 3 & 120 & 120 & 105 & 105 & 105 & 555 \\
\hline s6 & 6 & 120 & 120 & 105 & 105 & 105 & 555 \\
\hline s9 & 9 & 120 & 120 & 105 & 105 & 105 & 555 \\
\hline
\end{tabular}

Table 3 Sowing date, irrigation date and harvest date for maize of every year

\begin{tabular}{ccccccccc}
\hline & Sowing & Spring irrigation & 1st irrigation & 2nd irrigation & 3rd irrigation & 4th irrigation & 5th irrigation & Harvest \\
\hline 2012 & $4 / 24$ & $4 / 1$ & $6 / 6$ & $6 / 30$ & $7 / 21$ & $8 / 13$ & $8 / 31$ \\
2013 & $4 / 20$ & $4 / 5$ & $6 / 5$ & $6 / 30$ & $7 / 20$ & $8 / 10$ & $8 / 29$ \\
2014 & $4 / 19$ & $4 / 3$ & $6 / 10$ & $7 / 1$ & $7 / 25$ & $8 / 15$ & $9 / 5$ & $9 / 19$ \\
\hline
\end{tabular}

The fresh water used in the experiment was pumped directly from the groundwater in the study area. The fresh water contained $\mathrm{Na}^{+}+\mathrm{K}^{+}, \mathrm{Mg}^{2+}, \mathrm{Ca}^{2+}, \mathrm{HCO}_{3}^{-}, \mathrm{Cl}^{-}$and $\mathrm{SO}_{4}{ }^{2-}$ at $129.76 \mathrm{mg} / \mathrm{L}$, $31.9 \mathrm{mg} / \mathrm{L}, 45.7 \mathrm{mg} / \mathrm{L}, 41.19 \mathrm{mg} / \mathrm{L}, 150.19 \mathrm{mg} / \mathrm{L}$ and $296.22 \mathrm{mg} / \mathrm{L}$ concentrations respectively. Fresh water with a salinity of $0.71 \mathrm{~g} / \mathrm{L}$ was obtained from a local well. According to composition of the local groundwater, saline water of $3 \mathrm{~g} / \mathrm{L}, 6 \mathrm{~g} / \mathrm{L}$ and $9 \mathrm{~g} / \mathrm{L}$ was prepared artificially by dissolving $\mathrm{NaCl}, \mathrm{MgSO}_{4}$ and $\mathrm{CaSO}_{4}$ in fresh water in mass ratio of 2:2:1 respectively. The $\mathrm{pH}$ of different irrigation water was about 7 . The test pits was irrigated by pipelines and the water meter was used to control the irrigation water amount. Maize for seed production variety "Golden northwest No.22" was sowed in one-line male plants and seven-line female plants with 56 plants in each plot. Before sowing, whole plots were fertilized with $375 \mathrm{~kg} / \mathrm{hm}^{2}$ of $\mathrm{N}$, $225 \mathrm{~kg} / \mathrm{hm}^{2}$ of $\mathrm{P}_{2} \mathrm{O}_{5}$ and $300 \mathrm{~kg} / \mathrm{hm}^{2}$ of $\mathrm{K}_{2} \mathrm{O}$ as a basal fertilizer. When necessary, cultural practices, such as pest control, harrowing, and fertilization were followed following local experience.

\subsection{Meteorological data and sampling methods}

An automatic meteorological station (Weather Hark, Campbell Scientific, USA) was installed in the experimental station. Temperature, relative humidity, precipitation, wind speed and solar radiation were measured and the data was recorded every hour. Total effective precipitation $(\geq 2.5 \mathrm{~mm})$ during the maize growth stage in 2012, 2013 and 2014 was $109.7 \mathrm{~mm}, 51.2 \mathrm{~mm}$ and $141.2 \mathrm{~mm}$ respectively. The multi-year average precipitation during the maize growth was $90 \mathrm{~mm}$, which indicated that 2013 was a dry year, while 2012 and 2014 were wet years.

By using soil auger, the soil samples were taken before seeding, after harvest and before or after irrigation during the growth period of maize at a depth of $0-10 \mathrm{~cm}, 10-20 \mathrm{~cm}, 20-40 \mathrm{~cm}, 40-60 \mathrm{~cm}$, $60-80 \mathrm{~cm}$ and $80-100 \mathrm{~cm}$ per plot. The soil moisture was measured using drying method. The reserved soil samples were air dried, ground and passed through $1 \mathrm{~mm}$ sieve. A 1:5 soil-to-water ratio was used to prepare soil leachates. Electrical conductivity, $\mathrm{EC}_{1: 5}$ was measured using SG-3 conductivity meter (SG3-ELK742, Mettler-Toledo International Inc., Switzerland) and translated into soil salinity by using the equation, $S=0.0275 E C_{1: 5}+0.1366^{[23]}$. In 2014 during the maize growth period, soil samples were taken five times using steel cutting ring of $100 \mathrm{~cm}^{3}$ and $200 \mathrm{~cm}^{3}$ volume at the depth of $0-20 \mathrm{~cm}$ and $20-$ $40 \mathrm{~cm}$ per plot. The soil bulk density and soil porosity were measured by oven-drying method and saturated hydraulic conductivity was measured by soil permeability meter (TST-55, China) using constant head permeameter in triplicates for each treatment. To eliminate the influence of different temperature on saturated hydraulic conductivity, it was converted to the values of saturated hydraulic conductivity under $10^{\circ} \mathrm{C}$. The maize plant height, and length and width of leaf every 15-20 d after seedling were measured. The leaf area index ( $L A I)$, defined as the ratio of leaf area to land area was obtained using estimation formula ( $L A I=$ $(K \times L \times W) / A$, where $K$ is a fitting coefficient value, which for maize is $0.75^{[24]}$, and $A$ is the covering area of plant leaves). After harvest, maize yield components, such as ear length, ear diameter and aboveground dry matter were determined by taking average of 6 plants per plot. The weight of 100 grains for each plot was determined in triplicates. The maize for seed production from each plot were threshed and dried after harvest. The maize yields of each plot were measured to determine yield per hectare. The data obtained from experiments was analyzed using a single-factor analysis of variance (ANOVA) by SPSS 17.0 software package (SPSS Inc., Chicago, IL, USA).

\subsection{Calculation of water consumption and water use efficiency}

Water consumption and water use efficiency were calculated by the following equation.

$$
\begin{gathered}
E T=P_{0}+I-\Delta W-\mathrm{R}-\mathrm{L}+D \\
\Delta W=10 \times r H\left(W_{1}-W_{0}\right)
\end{gathered}
$$

where, ET is water consumption during the whole crop growth period, $\mathrm{mm} ; P_{0}$ is the total effective rainfall $(\geq 2.5 \mathrm{~mm}) ; I$ is the irrigation amount, $\mathrm{mm} ; \Delta W$ is the soil water depletion in the measured soil depth during the growing stage, $\mathrm{mm}$; and it was positive when soil water was recharged and negative when consumed; $W_{0}$ is soil moisture before sowing maize, $\mathrm{cm}^{3} / \mathrm{cm}^{3} ; W_{1}$ is soil moisture after harvest of maize, $\mathrm{cm}^{3} / \mathrm{cm}^{3} ; R$ is surface runoff and it is assumed to be zero, $\mathrm{mm} ; L$ is soil water side penetration $(\mathrm{mm})$ and it is assumed to be zero; $r$ is soil bulk density, $\mathrm{g} / \mathrm{cm}^{3}$; and $D$ is the bottom water flux of $0-100 \mathrm{~mm}$. The bottom water flux of $100 \mathrm{~cm}$ was estimated according to Darcy's equation $^{[25,26]}$, and was negative when downwards and positive when upwards.

According to Darcy's law, soil water exchange at the bottom of $100 \mathrm{~cm}$ can be estimated using equation:

$$
q=-K(\bar{\theta}) \operatorname{grad} H
$$

where, $q$ is the vertical water flux, $\mathrm{mm} / \mathrm{d} ; \bar{\theta}$ is the average soil moisture at $100 \mathrm{~cm}, \mathrm{~cm}^{3} / \mathrm{cm}^{3} ; \operatorname{grad} H$ is the hydraulic head gradient between $80-120 \mathrm{~cm}$; and $K(\bar{\theta})$ is unsaturated hydraulic conductivity, which is given by:

$$
K(\theta)=C(\theta) D(\theta)
$$

where, $\theta$ is soil volumetric moisture, $\mathrm{cm}^{3} / \mathrm{cm}^{3} ; C(\theta)$ is specific 
soil water capacity, $\mathrm{cm}$. The result can be obtained through the soil water retention curve, which is given by:

$$
\begin{gathered}
S=5.39468 \times 10^{5} e^{-26.886 \theta} \\
C(\theta)=6.895 \times 10^{-8} e^{26.886 \theta}
\end{gathered}
$$

where, $S$ is soil water suction, $\mathrm{cm} ; D(\theta)$ is soil water diffusion $\left(\mathrm{cm}^{2} / \mathrm{min}\right)$ that is determined by horizontal soil column method

$$
D(\theta)=0.0008 e^{21.275 \theta}
$$

Water use efficiency (WUE) is calculated as mentioned below:

$$
W U E=\frac{Y}{E T}
$$

where, $Y$ is the maize yield, $\mathrm{kg} / \mathrm{m}^{2}$.

\section{Results and discussion}

\subsection{Soil salt content distribution}

After saline water irrigation, the salt content in the soil is mainly influenced by irrigation, rainfall, irrigation water salinity, soil properties and the crop root water uptake. Figures 3 shows the salt content distribution with varying soil profiles under different treatments after saline water irrigation during the three years of study. We have stratified soil into three parts such as surface soil at a depth of $0-20 \mathrm{~cm}$, the crop root water uptake soil at a depth of 20-60 cm, and the deep soil at a depth of $60-100 \mathrm{~cm}$. Figures 3 shows that the salt content in the soil displays some pattern. Before irrigation, the salt content was stable across different layers. But after several rounds of saline water irrigation during the maize growth period, the salt content changed radically across different layers. After irrigation was stopped at the late stage of the growth, the salt content in the soil restored its stability. The salt content in the soil was obviously layered during the growth period of the maize under the $s 9, s 6$ and $s 3$ treatments over the three years of experiments following saline water irrigation. In detail, the salt content was lower in the surface soil, higher in the deep soil, and changed greatly in the crop root water uptake soil. Under the s0 treatment, the salt content changed slightly across different soil layers and was found to be around $0.5-1.0 \mathrm{~g} / \mathrm{kg}$ levels. However with s9, s6 and s3 treatments, the salt content in the soil across different soil layers was higher than freshwater irrigation, and the salt content increased with increase in salinity of the irrigation water. For surface soil and crop root water uptake soil, it was revealed that the salt content was highest for s9, followed by s6, then s3 and was lowest for s0. However, in the deep soil, very slight difference in salt content was found between s9 and s6 treatments.
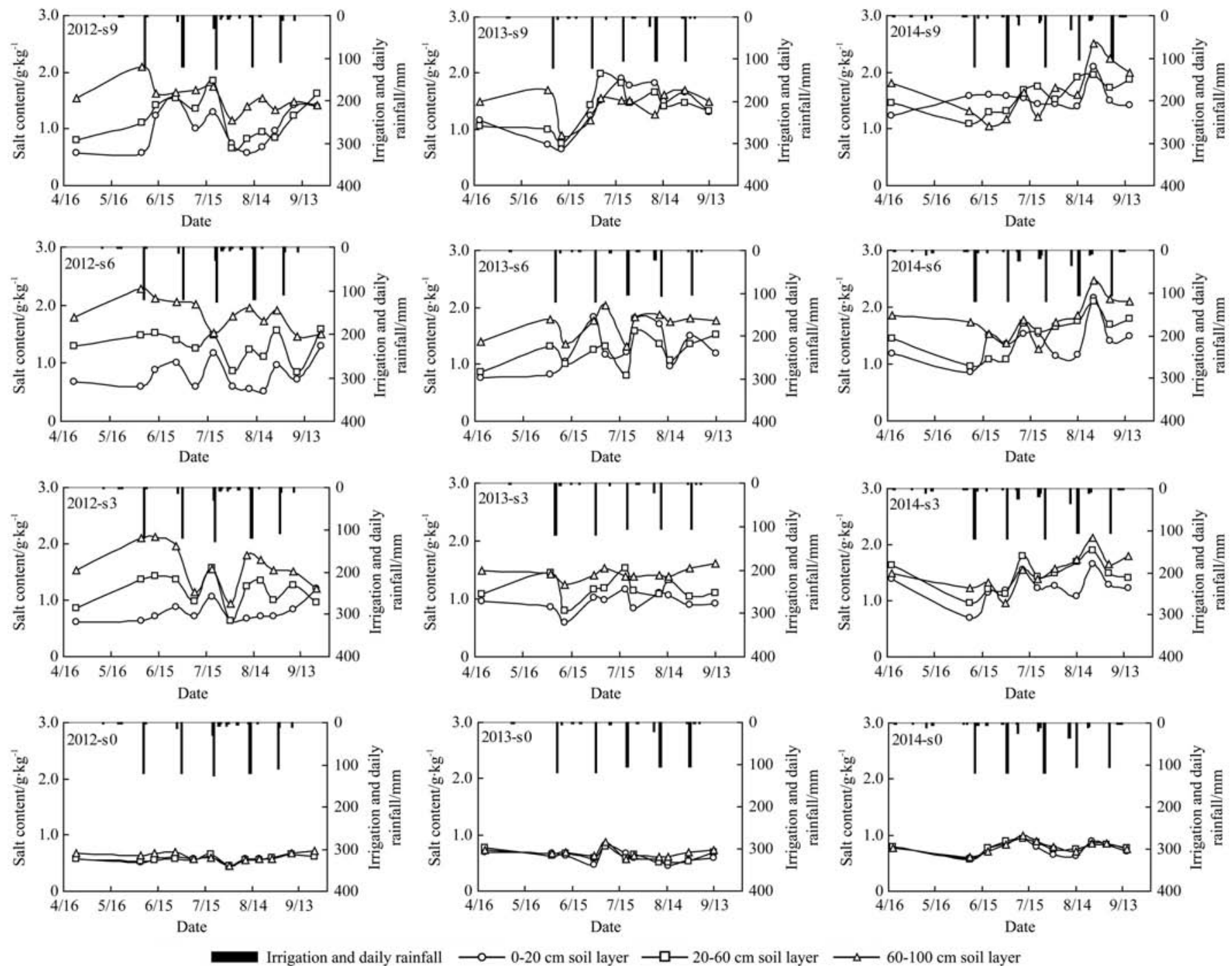

Figure 3 Salt content distribution in the soil under different treatments

Table 4 shows accumulation of salt content in the soil profile following different irrigation treatments in 2012, 2013 and 2014 after the maize harvest in comparison to that before the experiments. The positive value represents the salt deposit, while negative value depicts desalination. From this table, it can be observed that the accumulation of salt content across different soil 
layers increased with the saline water irrigation following s9, s6 and $\mathrm{s} 3$ treatments. The accumulation of salt content in the surface soil, crop root water uptake soil and deep soil following s9 treatment was $1.219 \mathrm{mg} / \mathrm{cm}^{3}, 1.194 \mathrm{mg} / \mathrm{cm}^{3}$ and $-0.204 \mathrm{mg} / \mathrm{cm}^{3}$ in 2012 and changed to $1.242 \mathrm{mg} / \mathrm{cm}^{3}, 1.567 \mathrm{mg} / \mathrm{cm}^{3}$ and $0.650 \mathrm{mg} / \mathrm{cm}^{3}$ respectively in 2014 . Upon s6 treatment, salt accumulation content was $0.914 \mathrm{mg} / \mathrm{cm}^{3}, 0.404 \mathrm{mg} / \mathrm{cm}^{3}$ and $-0.411 \mathrm{mg} / \mathrm{cm}^{3}$ in 2012 , which increased by $0.298,0.309$ and $0.885 \mathrm{mg} / \mathrm{cm}^{3}$ in 2014 in surface soil, crop root water uptake soil and deep soil respectively. Similarly, accumulation of salt content in 2012 following $\mathrm{s} 3$ treatment for surface soil, crop root water uptake soil and deep soil was $0.884 \mathrm{mg} / \mathrm{cm}^{3}, 0.158 \mathrm{mg} / \mathrm{cm}^{3}$ and $-0.484 \mathrm{mg} / \mathrm{cm}^{3}$ and further increased by $0.029 \mathrm{mg} / \mathrm{cm}^{3}$, $0.644 \mathrm{mg} / \mathrm{cm}^{3}$ and $0.861 \mathrm{mg} / \mathrm{cm}^{3}$ in 2014 respectively. The accumulation of salt content was consistently less than $0.3 \mathrm{mg} / \mathrm{cm}^{3}$ across the three different layers for all three years under the s0 treatment. The accumulation of salt content increased across the three layers following irrigation with saline water. For year 2014, the accumulation of salt content following s9, s6 and $\mathrm{s} 3$ treatments was $1.242 \mathrm{mg} / \mathrm{cm}^{3}, 1.212 \mathrm{mg} / \mathrm{cm}^{3}$ and $0.913 \mathrm{mg} / \mathrm{cm}^{3}$ respectively in the surface soil; $1.567 \mathrm{mg} / \mathrm{cm}^{3}, 0.713 \mathrm{mg} / \mathrm{cm}^{3}$ and $0.802 \mathrm{mg} / \mathrm{cm}^{3}$ in the crop root water uptake soil, and $0.650 \mathrm{mg} / \mathrm{cm}^{3}, 0.474 \mathrm{mg} / \mathrm{cm}^{3}$ and $0.377 \mathrm{mg} / \mathrm{cm}^{3}$ in the deep soil. Furthermore, the salt content was mostly concentrated in the surface and the crop root water uptake soil after saline water irrigation. In s6 treatment, the accumulation of salt content in surface soil, crop root water uptake soil and deep soil was $0.914 \mathrm{mg} / \mathrm{cm}^{3}, 0.404 \mathrm{mg} / \mathrm{cm}^{3}$, and $-0.411 \mathrm{mg} / \mathrm{cm}^{3}$ in 2012 and $1.212 \mathrm{mg} / \mathrm{cm}^{3}, 0.713 \mathrm{mg} / \mathrm{cm}^{3}$, and $0.474 \mathrm{mg} / \mathrm{cm}^{3}$ in 2014. This means that after irrigation was stopped at the late stage of growth, the salt content was concentrated in the surface and the crop root water uptake soil due to soil surface evaporation and crop root water uptake. It is found that the soil salt accumulation of 60-100 soil layer of s9, s6, s3 treatment in 2012, and s9, s6 treatment in 2013 was negative value. This was most possibly because that the field was implemented saline water irrigation trials since 2009 , the salt in surface soil was leached to deep soil by spring irrigation with a large water amount for last 3 years $^{[23]}$, thus, the initial soil salt at the soil depth of 60-100 cm under s9, s6, s3 were relatively higher. While, once the irrigation was ended at the end of maize growth, the soil salt will move to surface soil by soil evaporation and root water uptake. the soil salt was mainly accumulated in the surface soil, which induced lower soil salt at the depth of $60-100 \mathrm{~cm}$ after maize harvest, even lower than the very begin of the trial, and the negative value was appeared. It is needed to note that with the lasting years of saline water irrigation, the salt at the soil depth will accumulate to a positive value.

Table 4 Salt accumulation in the soil under different treatments

\begin{tabular}{|c|c|c|c|c|c|c|c|c|}
\hline \multirow[b]{2}{*}{ Treatment } & \multirow{2}{*}{$\begin{array}{l}\text { Soil depth } \\
\text { /mm }\end{array}$} & \multirow{2}{*}{$\begin{array}{c}\text { Salt content before the } \\
\text { experiment } \\
/ \mathrm{g} \cdot \mathrm{kg}^{-1}\end{array}$} & \multicolumn{2}{|c|}{2012} & \multicolumn{2}{|c|}{2013} & \multicolumn{2}{|c|}{2014} \\
\hline & & & $\begin{array}{l}\text { Salt content after } \\
\text { harvest } / \mathrm{g} \cdot \mathrm{kg}^{-1}\end{array}$ & $\begin{array}{l}\text { Salt accumulation } \\
\qquad / \mathrm{mg} \cdot \mathrm{cm}^{-3}\end{array}$ & $\begin{array}{l}\text { Salt content after } \\
\text { harvest } / \mathrm{g} \cdot \mathrm{kg}^{-1}\end{array}$ & $\begin{array}{l}\text { Salt accumulation } \\
\qquad / \mathrm{mg} \cdot \mathrm{cm}^{-3}\end{array}$ & $\begin{array}{l}\text { Salt content after } \\
\text { harvest } / \mathrm{g} \cdot \mathrm{kg}^{-1}\end{array}$ & $\begin{array}{l}\text { Salt accumulation } \\
\qquad / \mathrm{mg} \cdot \mathrm{cm}^{-3}\end{array}$ \\
\hline \multirow{3}{*}{ s9 } & $0-20$ & 0.576 & 1.399 & 1.219 & 1.307 & 1.082 & 1.415 & 1.242 \\
\hline & $20-60$ & 0.809 & 1.616 & 1.194 & 1.319 & 0.755 & 1.868 & 1.567 \\
\hline & $60-100$ & 1.551 & 1.413 & -0.204 & 1.484 & -0.099 & 1.990 & 0.650 \\
\hline \multirow{3}{*}{ s6 } & $0-20$ & 0.676 & 1.294 & 0.914 & 1.191 & 0.762 & 1.495 & 1.212 \\
\hline & $20-60$ & 1.304 & 1.577 & 0.404 & 1.519 & 0.317 & 1.786 & 0.713 \\
\hline & $60-100$ & 1.788 & 1.510 & -0.411 & 1.765 & -0.035 & 2.108 & 0.474 \\
\hline \multirow{3}{*}{ s3 } & $0-20$ & 0.611 & 1.208 & 0.884 & 0.915 & 0.450 & 1.228 & 0.913 \\
\hline & $20-60$ & 0.861 & 0.968 & 0.158 & 1.105 & 0.361 & 1.403 & 0.802 \\
\hline & $60-100$ & 1.538 & 1.211 & -0.484 & 1.616 & 0.115 & 1.793 & 0.377 \\
\hline \multirow{3}{*}{ s0 } & $0-20$ & 0.578 & 0.620 & 0.062 & 0.582 & 0.006 & 0.705 & 0.188 \\
\hline & $20-60$ & 0.576 & 0.611 & 0.052 & 0.680 & 0.154 & 0.770 & 0.287 \\
\hline & $60-100$ & 0.682 & 0.710 & 0.041 & 0.721 & 0.058 & 0.744 & 0.092 \\
\hline
\end{tabular}

Figure 4 shows variations of soil salt content in $0-100 \mathrm{~cm}$ depth with different treatments of saline water irrigation experiments. From this figure, it can be observed that the salt content in soil increased with every round of irrigation during maize growth under different treatments. The soil salt content increased faster when irrigation was done using high salinity water. In 2014, the salt content increased by $0.269 \mathrm{~g} / \mathrm{kg}, 0.293 \mathrm{~g} / \mathrm{kg}$ and
$0.002 \mathrm{~g} / \mathrm{kg}$ under s9, $\mathrm{s} 6$ and $\mathrm{s} 3$ treatments respectively compared to the salt content before sowing. In the three years of saline water irrigation, the soil salt content in the $0-100 \mathrm{~cm}$ depth under the $\mathrm{s} 9$, s6 and s3 treatments was higher than freshwater irrigation. The salt content in the soil under s9 and s6 treatments was much higher than s3. It was also observed that the soil salt content under s9 treatment did not differ much from salt content under s6 treatment.
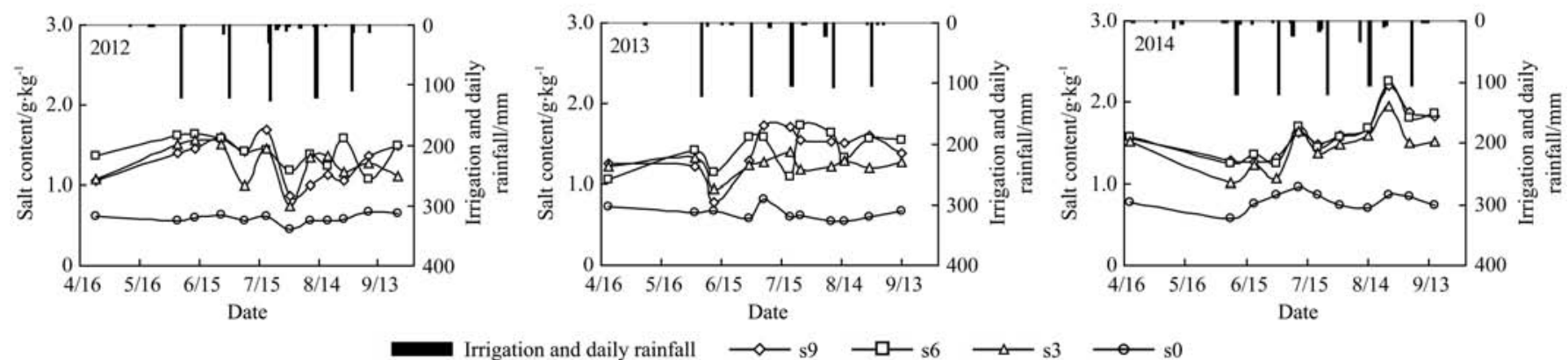

Figure 4 Soil salt content in $0-100 \mathrm{~cm}$ depth under different treatments 
Table 5 shows accumulation of salt content in $0-100 \mathrm{~cm}$ soil under different treatments post harvest for 2012, 2013 and 2014 in comparison to that in the beginning of the study. It can be observed that saline water irrigation led to accumulation of salt across different soil layers with time. The accumulation of salt content in 2012 was $0.640 \mathrm{mg} / \mathrm{cm}^{3}, 0.180 \mathrm{mg} / \mathrm{cm}^{3}$ and $0.046 \mathrm{mg} / \mathrm{cm}^{3}$ under s9, s6 and s3 treatments, respectively. These figures increased by $-0.161 \mathrm{mg} / \mathrm{cm}^{3}, 0.086 \mathrm{mg} / \mathrm{cm}^{3}$ and $0.235 \mathrm{mg} / \mathrm{cm}^{3}$ in 2013. The salt content accumulation further increased by $0.656 \mathrm{mg} / \mathrm{cm}^{3}, 0.451 \mathrm{mg} / \mathrm{cm}^{3}$ and $0.373 \mathrm{mg} / \mathrm{cm}^{3}$ in 2014 in comparison to that in 2013. On the contrary, under s0 treatment across three years, the salt accumulation was very little being 0.050 , 0.086 and $0.189 \mathrm{mg} / \mathrm{cm}^{3}$ for the year 2012, 2013 and 2014 , respectively. It can also be observed that after long-term saline water irrigation with $9 \mathrm{~g} / \mathrm{L}$ and $6 \mathrm{~g} / \mathrm{L}$, the salt content accumulation did not differ greatly in the $0-100 \mathrm{~cm}$ soil. This means that long-term irrigation with high-salinity saline water results in enormous concentration of salt in the soil. These results are similar to those previously reported by Jiang et al. ${ }^{[27]}$ and Wang et al. ${ }^{[23]}$ Hence, 9 $\mathrm{g} / \mathrm{L}$ and $6 \mathrm{~g} / \mathrm{L}$ salt water is not recommended for irrigation in the research area. In case of irrigation with $3 \mathrm{~g} / \mathrm{L}$ brackish water, salt content in the soil under saline water irrigation was observed to accumulate with time. In-depth investigation is needed to investigate whether the salt content accumulation in soil has serious influence on the soil's environment. The results showed that short-term brackish water irrigation with $3 \mathrm{~g} / \mathrm{L}$ salt concentration and salt leaching through spring irrigation before sowing each year cannot result in enormous concentration of salt in the soil.

Table 5 Soil salt accumulation in the $0-100 \mathrm{~cm}$ under different treatments

\begin{tabular}{|c|c|c|c|c|c|c|c|}
\hline \multirow{2}{*}{ Treatment } & \multirow{2}{*}{$\begin{array}{l}\text { Salt content before } \\
\text { experiment } \\
/ \mathrm{g} \cdot \mathrm{kg}^{-1}\end{array}$} & \multicolumn{2}{|c|}{2012} & \multicolumn{2}{|c|}{2013} & \multicolumn{2}{|c|}{2014} \\
\hline & & $\begin{array}{l}\text { Salt content after } \\
\text { harvest } / \mathrm{g} \cdot \mathrm{kg}^{-1}\end{array}$ & $\begin{array}{l}\text { Salt accumulation } \\
\quad / \mathrm{mg} \cdot \mathrm{cm}^{-3}\end{array}$ & $\begin{array}{l}\text { Salt content after } \\
\text { harvest } / \mathrm{g}^{-\mathrm{kg}^{-1}}\end{array}$ & $\begin{array}{l}\text { Salt accumulation } \\
\qquad / \mathrm{mg} \cdot \mathrm{cm}^{-3}\end{array}$ & $\begin{array}{l}\text { Salt content after } \\
\text { harvest } / \mathrm{g}^{-\mathrm{kg}^{-1}}\end{array}$ & $\begin{array}{l}\text { Salt accumulation } \\
\qquad / \mathrm{mg} \cdot \mathrm{cm}^{-3}\end{array}$ \\
\hline s9 & 1.059 & 1.491 & 0.640 & 1.383 & 0.479 & 1.826 & 1.135 \\
\hline s6 & 1.372 & 1.494 & 0.180 & 1.551 & 0.266 & 1.857 & 0.717 \\
\hline s3 & 1.082 & 1.113 & 0.046 & 1.271 & 0.281 & 1.524 & 0.654 \\
\hline s0 & 0.619 & 0.652 & 0.050 & 0.677 & 0.086 & 0.747 & 0.189 \\
\hline
\end{tabular}

3.2 Influence of saline water irrigation on soil physical properties

The soil bulk density and soil porosity are the basic parameters of physical properties of soil. As one of the physical properties of soil, saturated hydraulic conductivity is an important measure of determining soil permeability and highly relates to soil bulk density and soil porosity. The long-term saline water irrigation causes increased concentration of salt content in the soil profile, and inevitably exerts influence on soil bulk density, soil porosity and saturated hydraulic conductivity ${ }^{[28,29]}$. Figure 5 shows variations in the soil bulk density, soil porosity and saturated hydraulic conductivity during the maize growth period in 2014. The soil at the crop taproot layer $(0-40 \mathrm{~cm})$ was ploughed again before maize was planted in the experimental area and then was leached through spring irrigation with the purpose of eliminating the difference of the soil across different experimental areas in terms of soil bulk density, soil porosity and saturated hydraulic conductivity. It can also be seen from Figure 5 that soil bulk density increased with raising rounds of saline water irrigation for different water salinity treatments. Compared to pre sowing, the soil bulk density of 0 $20 \mathrm{~cm}$ soil after maize harvest in 2014 under the s9, s6, s3 and s0 treatments increased by $4.31 \%, 2.95 \%, 2.86 \%$ and $0.33 \%$, respectively, while the soil bulk density of $20-40 \mathrm{~cm}$ soil increased by $2.29 \%, 1.35 \%, 1.27 \%$ and $0.16 \%$, respectively. Therefore, higher salinity of irrigation water leads to higher soil bulk density. Meanwhile, the soil porosity and saturated hydraulic conductivity decreased as rounds of saline water irrigation raised. Furthermore, the variations in soil porosity and saturated hydraulic conductivity under different treatments revealed the same patterns as that observed for soil bulk density.
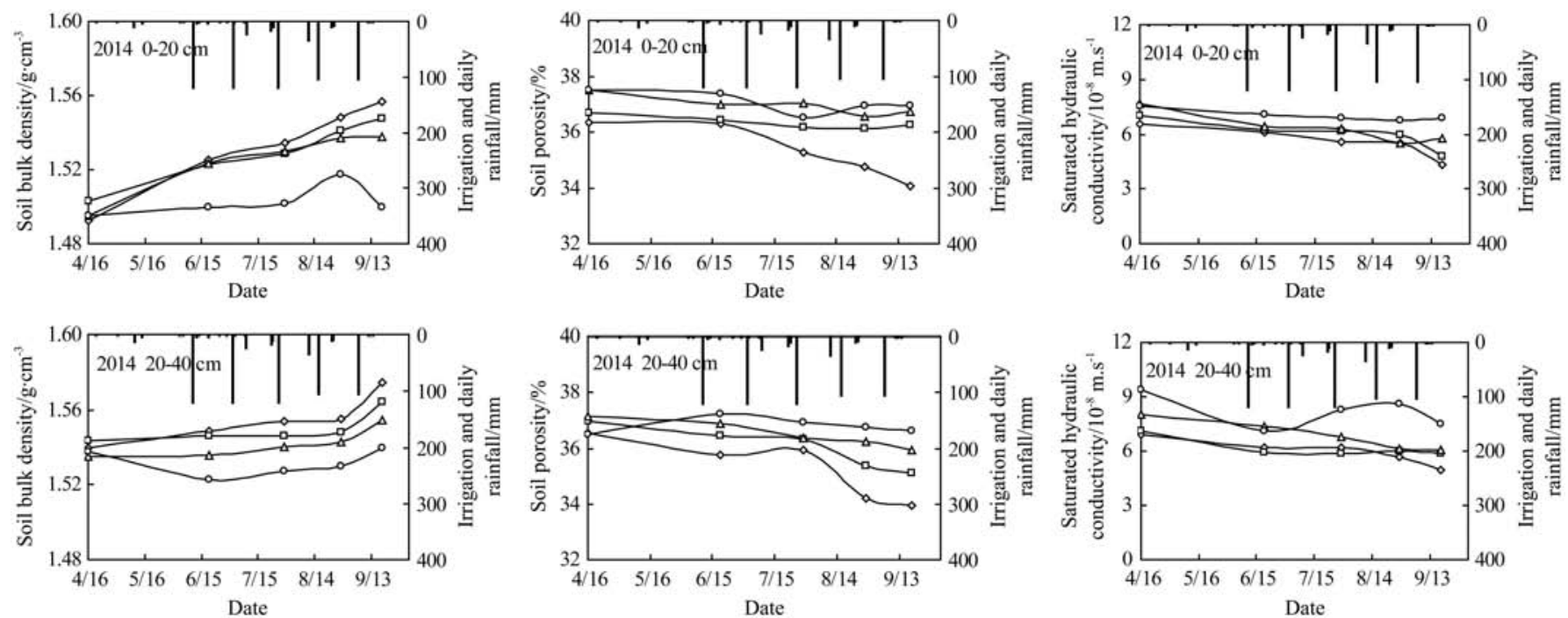

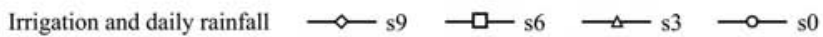

Figure 5 Bulk density, porosity and saturated hydraulic conductivity of the soil 
Figure 6 shows the correlation between soil bulk density, soil porosity and saturated hydraulic conductivity. It can be seen from the figures that saturated hydraulic conductivity has negative correlation with the soil bulk density and positive correlation with
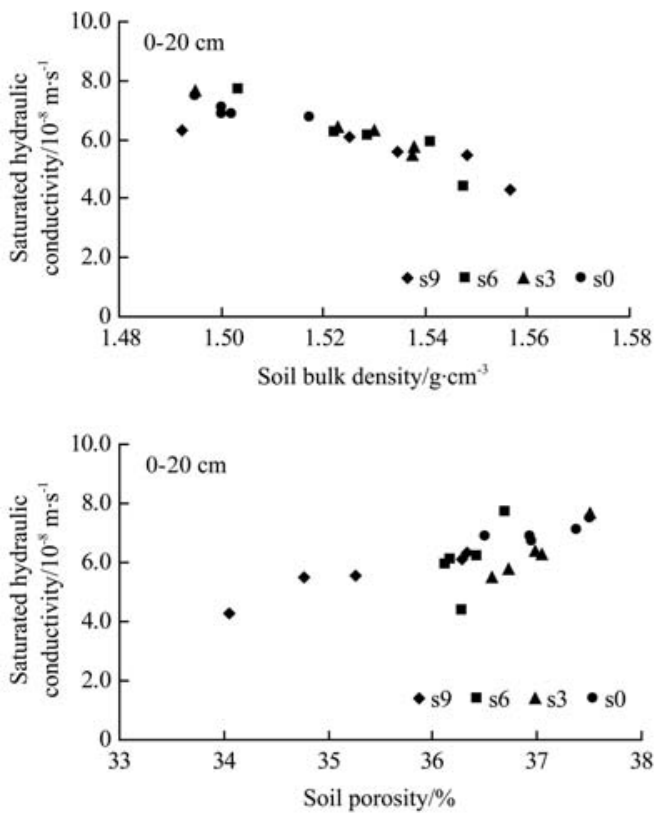

soil porosity. It can be explained that the increase of soil bulk density results in compact soil, thereby inducing reduced porosity and poor saturated hydraulic conductivity of the soil.
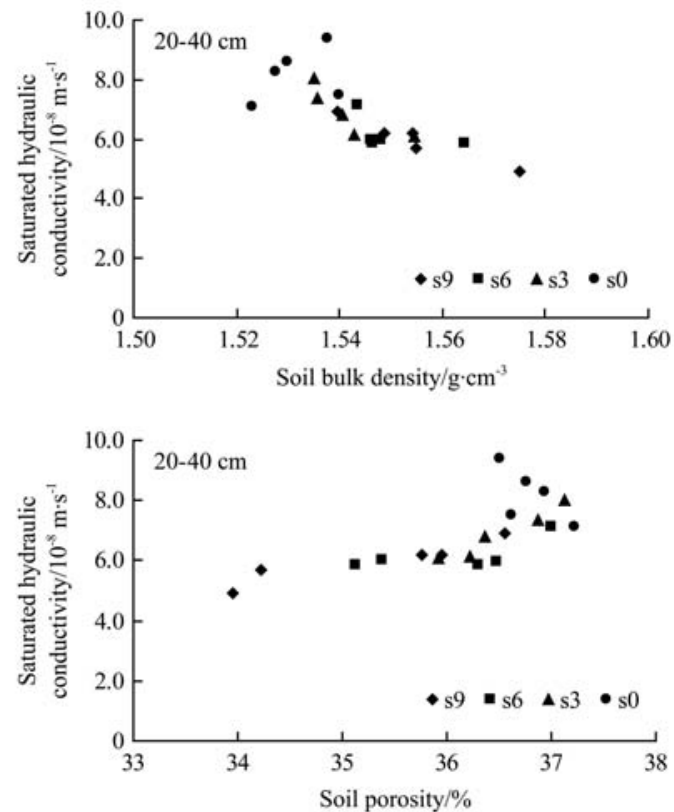

Figure 6 Relationship between bulk density, porosity and saturated hydraulic conductivity

\subsection{Influence of saline water irrigation on plant height and leaf area index of maize for seed production}

Figures 7 shows the variation of maize for seed production height and leaf area index (LAI) following s0, s3, s6 and s9 treatments during the three experimental years. The maize plant height changed radically during the growth. Before booting stage, the plant grew quickly and plant height increased dramatically. After booting stage, plant height remained almost the same. The influence of saline water irrigation on maize plant height became obvious after the jointing stage. At the late stage of growth in 2012 , the plant height for s3, s6 and s9 treatments was $3.22 \%$, $5.00 \%$ and $11.45 \%$ less than that with s0 treatment, by $5.42 \%$, $12.23 \%$ and $19.97 \%$ in 2013 , and by $2.92 \%, 7.19 \%$ and $12.10 \%$ in 2014 respectively. Hence, irrigation with higher salinity water greatly influences maize plant height. The influence of various saline water irrigation treatments on plant height in 2012 and 2014 was less than that in 2013. In years 2012 and 2014, there was heavy rainfall that probably leached salt from the soil and thus reduced influence of saline water irrigation on plant height. LAI of maize also showed changes similar to that observed for plant height after different water salinity treatments. At the late stage of growth in 2012, LAI under s3, s6 and s9 treatments was less than s0 by $4.95 \%, 9.87 \%$ and $18.12 \%$, by $17.60 \%, 39.84 \%$ and $48.38 \%$ in 2013 , and by $13.11 \%, 19.30 \%$ and $27.00 \%$ in 2014 respectively. Hence, saline water irrigation reduces both the maize plant height and LAI. Additionally, irrigation with higher salinity water has a greater influence on the maize growth. Long-term irrigation with high-salinity salt water severely affected crop growth. The influence of the salt content on maize plant height and LAI during the three years of experiment was insignificant $(p>0.05)$.
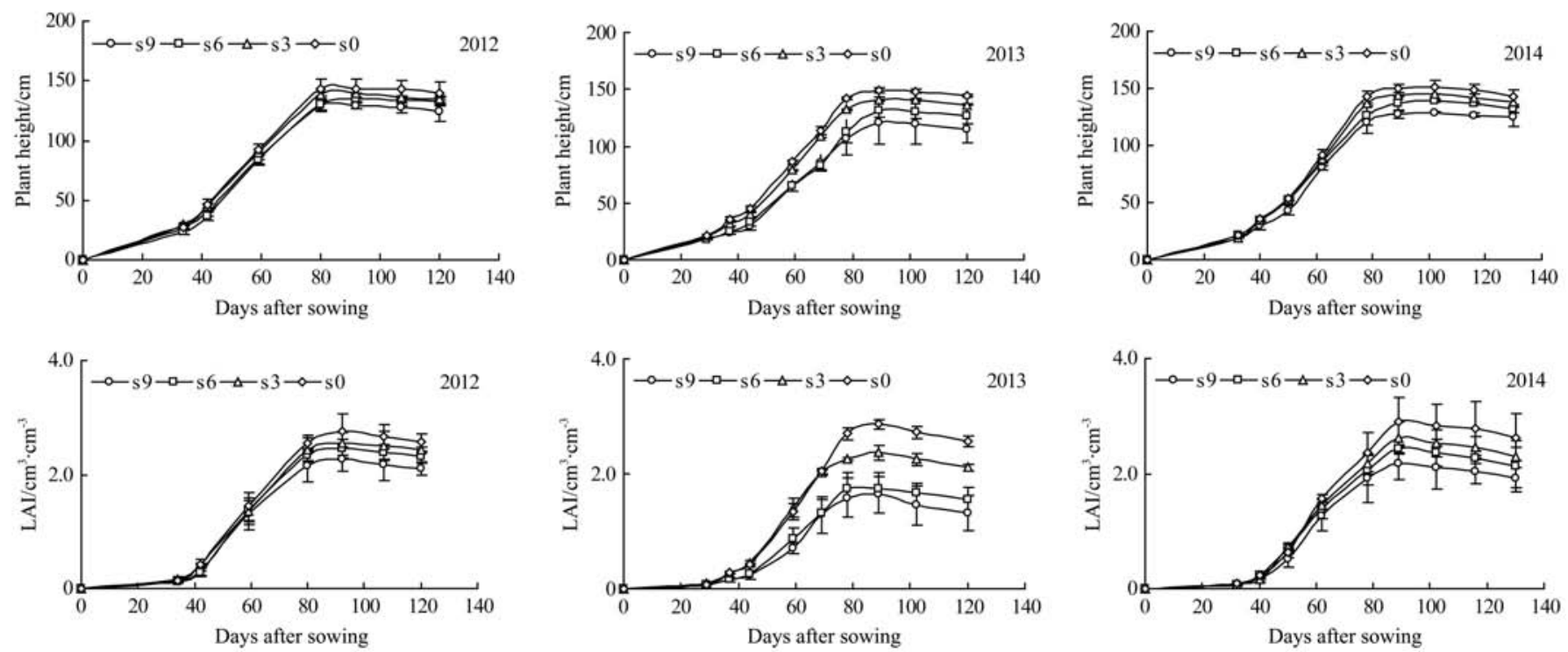

Figure 7 Plant height and LAI of maize for seed production across different days after sowing 
3.4 Influence of saline water irrigation on maize for seed production yield

Table 6 shows maize for seed production yield and the yield parameters under different treatments during 2012-2014.

The maximum value of the maize yield under $\mathrm{s} 0$ treatment in 2012 was $6303.36 \mathrm{~kg} / \mathrm{hm}^{2}$, which was higher than s3, s6 and s9 by $17.39 \%, 25.65 \%$ and $35.33 \%$, respectively. Similarly, the maize yield under s0 treatment in 2013 was $5838.60 \mathrm{~kg} / \mathrm{hm}^{2}$ and was $19.65 \%, 29.53 \%$ and $33.63 \%$ higher than that with s3, s6 and s9 treatments, respectively. In 2014, the maize yield under s0 treatment was $6019.07 \mathrm{~kg} / \mathrm{hm}^{2}$ and was higher than $\mathrm{s} 3$, s6 and s9 treatment by $18.19 \%, 29.08 \%$ and $32.76 \%$, respectively. The influence of saline water irrigation on maize ear length, ear diameter, hundred-grain weight and dry matter weight was similar to its influence on the yield. Hence, higher the salinity of the irrigation water is, greater the decrease in maize yield occurs. Three years of saline water irrigation with $6 \mathrm{~g} / \mathrm{L}$ and $9 \mathrm{~g} / \mathrm{L}$ resulted in a decrease of over $25 \%$ in maize yield. Saline water irrigation with $3 \mathrm{~g} / \mathrm{L}$ resulted in reduction in the maize yield by less than $20 \%$. These results are similar to those reported previously by Jiang et al. ${ }^{[2]}$ and Wang et al. ${ }^{[23]}$ However, short-term irrigation with $3 \mathrm{~g} / \mathrm{L}$ brackish water in the research area will not cause dramatic reduction in maize yield. Variance analysis was performed on maize yield and yield parameters during 2012-2014. The different irrigation water salinity treatments were subjected to LSD test $(p<0.05)$. Results indicate that the salt content had significant influence on the hundred-grain weight and yield in 2012; on ear length, dry matter weight and yield in 2013; and on ear diameter and hundred-grain weight in 2014. However, the salt content did not have a significant influence on any other yield parameters.

Table 6 Yield and yield parameters of maize for seed production

\begin{tabular}{|c|c|c|c|c|c|c|}
\hline Year & Treatment & Ear length/cm & Ear diameter $/ \mathrm{cm}$ & Hundred-grain weight/g & Dry matter weight/g & Yield $/ \mathrm{kg} \cdot \mathrm{hm}^{-2}$ \\
\hline \multirow{4}{*}{2012} & s9 & $127.76( \pm 7.42) \mathrm{a}$ & $37.83( \pm 4.11) \mathrm{a}$ & $28.10( \pm 0.37) \mathrm{a}$ & $128.78( \pm 35.53) \mathrm{a}$ & $4076.22( \pm 271.22) \mathrm{a}$ \\
\hline & s6 & $136.41( \pm 13.50) \mathrm{ac}$ & $39.28( \pm 2.12) \mathrm{ab}$ & $32.23( \pm 0.34) b$ & $143.39( \pm 12.36) \mathrm{a}$ & $4686.73( \pm 351.10) \mathrm{b}$ \\
\hline & s3 & $151.59( \pm 3.09) \mathrm{bc}$ & $42.63( \pm 2.38) \mathrm{b}$ & $33.00( \pm 0.56) \mathrm{c}$ & $174.52( \pm 51.67) \mathrm{a}$ & $5207.4( \pm 254.05) \mathrm{c}$ \\
\hline & s0 & $166.26( \pm 10.81) b$ & $43.19( \pm 1.67) b$ & $35.60( \pm 1.10) \mathrm{d}$ & $196.28( \pm 52.16) \mathrm{a}$ & $6303.36( \pm 180.77) \mathrm{d}$ \\
\hline \multirow{3}{*}{2013} & s9 & $121.59( \pm 3.84) \mathrm{a}$ & $35.53( \pm 3.87) \mathrm{a}$ & $29.45( \pm 1.85) \mathrm{a}$ & $115.23( \pm 3.01) \mathrm{a}$ & $3875.15( \pm 27.28) \mathrm{a}$ \\
\hline & s3 & $148.15( \pm 0.61) \mathrm{c}$ & $42.19( \pm 0.77) \mathrm{a}$ & $32.66( \pm 1.83) \mathrm{ab}$ & $185.37( \pm 3.07) \mathrm{c}$ & $4691.10( \pm 81.67) \mathrm{c}$ \\
\hline & s0 & $159.52( \pm 2.84) \mathrm{d}$ & $46.26( \pm 0.51) \mathrm{b}$ & $35.83( \pm 1.16) \mathrm{b}$ & $193.21( \pm 11.68) \mathrm{d}$ & $5838.60( \pm 415.02) \mathrm{d}$ \\
\hline \multirow{4}{*}{2014} & s9 & $132.26( \pm 9.36) \mathrm{a}$ & $35.48( \pm 1.09) \mathrm{a}$ & $27.84( \pm 1.25) \mathrm{a}$ & $131.55( \pm 9.75) \mathrm{a}$ & $4047.1( \pm 436.50) \mathrm{a}$ \\
\hline & s6 & $138.49( \pm 7.80) b$ & $37.63( \pm 1.61) b$ & $31.34( \pm 0.49) \mathrm{b}$ & $149.4( \pm 13.05) \mathrm{a}$ & $4268.8( \pm 85.39) \mathrm{a}$ \\
\hline & s3 & $153.17( \pm 5.76) b c$ & $39.12( \pm 1.68) \mathrm{c}$ & $33.76( \pm 1.21) \mathrm{c}$ & $175.68( \pm 28.85) b$ & $4924.24( \pm 579.07) \mathrm{a}$ \\
\hline & s0 & $169.54( \pm 7.23) \mathrm{c}$ & $42.36( \pm 0.47) \mathrm{d}$ & $35.98( \pm 0.67) \mathrm{d}$ & $204.09( \pm 32.34) b c$ & $6019.07( \pm 727.84) b$ \\
\hline
\end{tabular}

Note: Values in arrow followed by the same letter are not significantly different at $p<0.05$.

\subsection{Influence of saline water irrigation on water use efficiency of maize for seed production}

Table 7 shows that the water use efficiency under different treatments during 2012-2014. Under different irrigation methods based on varying salinity, despite the total water consumption of maize was similar, the water use efficiency were distinct. As salinity of the water raised, water use efficiency decreased. In 2012, the water use efficiency of s0 that irrigated by fresh water was found to $1.02 \mathrm{~kg} / \mathrm{m}^{3}$, and reduced by $17.19 \%, 19.89 \%$ and $24.98 \%$ for s3, s6, and s9, respectively. Similarly, during 2013, the water use efficiency of s0 was $1.03 \mathrm{~kg} / \mathrm{m}^{3}$ and reduced by $14.8 \%, 25.00 \%$ and $28.66 \%$ for $\mathrm{s} 3, \mathrm{~s} 6$, and $\mathrm{s} 9$, respectively. By the 3rd year (2014), the water use efficiency of s0 was found to
$1.00 \mathrm{~kg} / \mathrm{m}^{3}$ with reduction in $\mathrm{s} 3$, s6, and $\mathrm{s} 9$ by $16.36 \%, 24.11 \%$ and $31.53 \%$, respectively. It was observed that the water use efficiency of s6 and s9 gradually reduced with increased saline water irrigation rounds. The water use efficiency of $s 6$ and s9 declined each year from $0.76 \sim 0.76 \mathrm{~kg} / \mathrm{m}^{3}$ in 2012 to $0.68 \sim$ $0.76 \mathrm{~kg} / \mathrm{m}^{3}$ in 2014, respectively. Additionally, relatively gent change in water use efficiency of $\mathrm{s} 3$ was observed from $0.84 \mathrm{~kg} / \mathrm{m}^{3}$ in 2012 to $0.83 \mathrm{~kg} / \mathrm{m}^{3}$ in 2014 . However, it is need to note that the water use efficiency of $\mathrm{s} 0$ was retained at around $1.0 \mathrm{~kg} / \mathrm{m}^{3}$ during the study period. In brief, short-term saline water irrigation below $3 \mathrm{~g} / \mathrm{L}$ together with annual salt leaching through spring irrigation before sowing did not strikingly reduce the water use efficiency of maize.

Table 7 Water use efficiency of maize for seed production

\begin{tabular}{|c|c|c|c|c|c|c|c|c|c|c|c|c|c|c|c|c|}
\hline \multirow{2}{*}{ Treatment } & \multirow{2}{*}{$\begin{array}{l}\text { Total irrigation } \\
\text { quota/mm }\end{array}$} & \multicolumn{3}{|c|}{ Precipitation $/ \mathrm{mm}$} & \multicolumn{3}{|c|}{ Soil water depletion $/ \mathrm{mm}$} & \multicolumn{3}{|c|}{$\begin{array}{c}\text { Bottom water flux of } \\
0-100 \mathrm{~cm} / \mathrm{mm}\end{array}$} & \multicolumn{3}{|c|}{$\mathrm{ET} / \mathrm{mm}$} & \multicolumn{3}{|c|}{$\mathrm{WUE} / \mathrm{kg} \cdot \mathrm{m}^{-3}$} \\
\hline & & 2012 & 2013 & 2014 & 2012 & 2013 & 2014 & 2012 & 2013 & 2014 & 2012 & 2013 & 2014 & 2012 & 2013 & 2014 \\
\hline s9 & 555 & 109.7 & 51.2 & 141.2 & 38.3 & -5.6 & -3.3 & -93.4 & -82.5 & -106 & 533.0 & 529.3 & 593.4 & 0.76 & 0.73 & 0.68 \\
\hline s6 & 555 & 109.7 & 51.2 & 141.2 & 5.1 & -7.2 & 29.1 & -85.7 & -78.6 & -102 & 573.9 & 534.8 & 564.7 & 0.82 & 0.77 & 0.76 \\
\hline s3 & 555 & 109.7 & 51.2 & 141.2 & -22.9 & 8.2 & 6.9 & -70.8 & -61.4 & -98.2 & 616.8 & 536.6 & 591.1 & 0.84 & 0.88 & 0.83 \\
\hline
\end{tabular}

\section{Conclusions}

We performed saline water irrigation experiments for three consecutive years to study its effects on soil salt content distribution, soil physical properties and water use efficiency of maize for seed production in the Shiyang River basin of Northwest China. The main conclusions of this study are that the salt content in the soil profile was obviously layered after saline water irrigation 
during the growth period. The salt content was low in surface soil, high in deep soil, and changed greatly in root zone soil after saline water irrigation during the growth period. The accumulation of salt content increased with water salinity and irrigation times of saline water. Compared to the initial situation, the accumulation of salt content under s0, s3, s6 and s9 were $0.189 \mathrm{mg} / \mathrm{cm}^{3}$, $0.654 \mathrm{mg} / \mathrm{cm}^{3}, 0.717 \mathrm{mg} / \mathrm{cm}^{3}$ and $1.135 \mathrm{mg} / \mathrm{cm}^{3}$ after three consecutive years, respectively. The soil bulk density, soil porosity and saturated hydraulic conductivity changed with salt accumulation in the soil profile after saline water irrigation. The soil bulk density increased, while the soil porosity and saturated hydraulic conductivity decreased. With the increase in both the irrigation water salinity and irrigation times, the saturated hydraulic conductivity and soil porosity reduced, while the soil bulk density increased.

The maize growth and yield were inhibited with gradual salt accumulation and the variations in soil physical properties were observed. The plant height, LAI, yield and yield parameters of maize decreased with increased irrigation water salinity. The maize yield decreased over $25 \%$ and the water use efficiency gradually declined after irrigation with $6 \mathrm{~g} / \mathrm{L}$ and $9 \mathrm{~g} / \mathrm{L}$ saline water. However, maize yield following irrigation with $3 \mathrm{~g} / \mathrm{L}$ of saline water decreased less than $20 \%$ and decline in water use efficiency was not obvious during the three year study period. Hence, saline water irrigation with $6 \mathrm{~g} / \mathrm{L}$ and $9 \mathrm{~g} / \mathrm{L}$ was found to be not suitable in the study area. In the case of irrigation with $3 \mathrm{~g} / \mathrm{L}$ saline water, further experiment needs to be performed to investigate whether the salt content accumulation in the soil has any serious influence on soil environment and crop yield. The short-term saline water irrigation with $3 \mathrm{~g} / \mathrm{L}$ in the research area, together with annual salt leaching through spring irrigation before sowing, is recommended for practice.

\section{Acknowledgements}

This research was financially supported by National Natural Science Foundation of China (51179166), Specialized Research Fund for the Doctoral Program of Higher Education of China (20123250110004), and A Project Funded by the Priority Academic Program Development of Jiangsu Higher Education Institutions(PAPD).

\section{[References]}

[1] Kang S Z, Su X L, Tong L, Shi P Z, Yang X Y, Abe Y K,et al. The impacts of human activities on the water-land environment of the ShiyangRiver basin, an arid region in northwest China. Hydrological Sciences Journal, 2004; 49(3): 68-76.

[2] Zheng J H, Huang G H, Wang J, Huang Q Z, Pereira L S, Xu X, et al. Effects of water deficits on growth, yield and water productivity of drip-irrigated onion (Allium cepa L.) in an arid region of Northwest China. Irrigation Science, 2013; 31: 995-1008.

[3] Jiang J, Huo Z L, Feng S Y, Kang S Z, Wang F X, Zhang C B .Effect of irrigation amount and water salinity on water consumption and water productivity of spring wheat in Northwest China. Field Crop Research, 2013; 137: 78-88.

[4] Dutt G R, Pennington D A, Turner F. Irrigation as a solution to salinity problems of river basins. In: Salinity in Watercourses and Reservoirs. Ann Arbor Science Michigan, 1984; 465-472.

[5] Sampson K. Irrigation with saline water in the Sheraton irrigation region. Jr. soil water conservation, 1996; 9(3): 9-33.

[6] Pasternak D, De Malach Y. Irrigation with brackish water under desert conditions $\mathrm{X}$. Irrigation management of tomatoes (Lycopersicon esculentum Mills) on desert sand dunes. Agricultural Water Management, 1995; 28(2): 121-132.

[7] Silberstein R P, Vertessy R A, Morris J, Feikema P M. Modeling the effects of soil moisture and solute conditions on long-term tree growth and water use: a case study from the Shepparton irrigation area, Australia. Agricultural Water Management1999; 39: 283-315.

[8] Salama R B, Otto C J, Fitzpatrick P W. Contribution of ground conditions to soil and water salinization. Hydrogeology Journal, 1999; 7: 46-64.

[9] Valenza A, Grillot J C, Dazy J. Influence of groundwater on degradation of irrigated soils in a semi-arid region, the inner delta of the Niger River Mali. Hydrogeology Journal, 2000; 8: 417-429.

[10] Jorenush M H, Sepaskhah A R. Modelling capillary rise and soil salinity for shallow saline water table under irrgated and non-irrigated conditions. Agricultural Water Management, 2003; (1813): 1-17.

[11] Tedeschi A, Menenti M. Simulation studies of long term saline water use model validation and evaluation of schedules. Agricultural Water Management, 2002; 54: 123-157.

[12] Postiglione L, Barbieri G, Tedeschi A. Long-term effects of irrigation with saline water on some characteristics of a clay loam soil. Rivista Di Agronomia, 1995; 29: 24-30.

[13] Tedeschi A, Aquila R D. Effects of irrigation with saline waters, at different concentrations, on soil physical and chemical characteristics. Agricultural Water Management, 2005; 77: 308-322.

[14] Shainberg I, Rhoades J D, Prather R J. Effect of tow electrolyte concentration on clay dispersion and hydraulic conductivity of a sodic soil. Soil Science Society of America Journal, 1981; 45: 273-277.

[15] Feigen A, Ravina I, Shalhevet J. Effect of irrigation with treated sewage effluent on soil, plant and environment. Irrigation with treated sewage effluent: management for environmental protection. Berlin: Springer-Verlag, 1991; 34-116.

[16] Zartman R E, Gichuru M. Saline irrigation water effect on soil chemical and physical properties. Soil Science, 1984; 138(6): 417-422.

[17] Mass, E V, Grattan, S R. Crop yields as affected by salinity. In: Skaggs R W, van Schilfgaarde J (Eds.), Agricultural Drainage, 1999; pp.55-108.

[18] Panda R K, Behera S K, Kashyap P S. Effective management of irrigation water for maize under stressed conditions. Agricultural Water Management, 2004; 66: 181-203.

[19] Leogrande, R,Vitti C, Lopedota O, Ventrella D, Montemurro F. Effects on irrigation volume and water on maize yield and soil in southern Italy. Irrigation and Drainage, 2016; 65(3): 243-253.

[20] Katerji N, van Hoorn J W, Hamdy A, Karam F, Mastrorilli A. Effect of salinity on water stress, growth, and yield of maize and sunflower. Agricultural Water Management, 1996; 30: 237-249.

[21] Kang Y H, Chen M, Wan S Q. Effects of drip irrigation with saline water on waxy (Zea mays L. var. ceratina Kulesh) in North China Plain. Agricultural Water Management, 2010; 97: 1303-1309.

[22] Tong L. Impacts of environment change on agricultural water consumption in Shiyang River Basin in arid region of Northwest China. Northwest Sci-Tech University of Agriculture and Forestry, Shanxi, 2007.

[23] Wang Q M, Huo Z L, Zhang L D, Wang J H, Zhao Y. Impact of saline water irrigation on water use efficiency and soil salt accumulation for spring maize in arid region of China. Agricultural Water Management, 2016; 163: 125-138.

[24] Li S E, Kang S Z, Li F S, Zhang L. Evapotranspiration and crop coefficient of spring maize with plastic mulch using eddy covariance in Northwest China. Agricultural Water Management, 2008; 97: 1214-1222.

[25] Ma Y, Feng S Y, Huo Z L, Song X F. Application of the SWAP model to simulate the field water cycle under deficit irrigation in Beijing, China, Mathematical and Computer Modelling, 2011; 54: 1044-1052.

[26] Jiang J, Huo Z L, Feng S Y, Zhang C B. Effect of irrigation amount and water salinity on water consumption and water productivity of spring wheat in Northwest China. Field Crop Research, 2012; 137: 78-88.

[27] Jiang J, Feng S Y, Huo Z L, Wang Y S, Sun Z H. Effect of irrigation with saline water on soil water-salt dynamics and maize yield in arid Northwest China. Wuhan University Journal of Natural Science, 2010; 15(1): 85-92.

[28] Bhardwaj A K, Mandal U K, Bar-Tal A. Replacing saline-sodic irrigation water with treated wastewater: effects on saturated hydraulic conductivity, slaking, and swelling. Irrigation Science, 2008; 26: 139-146.

[29] Huang C H, Xue X, Wang T, Mascellis R D, Mele G, You Q G, et al. Effects of saline water irrigation on soil properties in northwest China. Environmental Earth Sciences, 2010; 63(4): 701-708. 